\title{
Dump Valve Device
}

National Cancer Institute

\section{Source}

National Cancer Institute. Dump Valve Device. NCI Thesaurus. Code C50246.

A outflow valve designed to quickly empty a system. 